\title{
Renoprotective role of ACE inhibitors in diabetic nephropathy
}

\author{
Carl Erik Mogensen
}

Patients with diabetes mellitus and overt proteinuria have a poor prognosis. ${ }^{1}$ Recent studies show that appreciable proteinuria is associated with a much more rapid progression of disease than is moderate albuminuria. ${ }^{2}$ Progression is also closely associated with raised blood pressure, but appreciable albuminuria in itself seems to be an important prognostic indicator.

Before clinical proteinuria occurs (macroalbuminuria) patients always go through a stage of microalbuminuria, often lasting 10 years. Diabetic renal disease develops in stages, especially in patients with insulin dependent diabetes. ${ }^{3-5}$ Classification according to the degree of albuminuria is important because patients with perfectly normal albumin excretion rates usually have a good long term prognosis, although some (about $4 \%$ per year) of them will progress from normoalbuminuria to microalbuminuria. ${ }^{6}$ On the other hand, patients with persistent microalbuminuria have (without intervention) a much poorer prognosis, with a much higher risk of progression to overt renal disease over the following decade. ${ }^{3}$ According to new morphometric studies, this is not surprising because microalbuminuria indicates that patients are in a more advanced stage of glomerular disease. ${ }^{7}$

In this paper I will review data on intervention with ACE inhibitors throughout the course of diabetes. Editorials in three major journals recently discussed this important issue. $^{8-10}$ Table 1 shows an outline of the stages of diabetic renal involvement and disease in patients with insulin dependent diabetes from the time of diagnosis of diabetes. Poor glycaemic control is an important factor determining transition to microalbuminuria and probably progression of the microalbuminuric state, ${ }^{6} 112$ but metabolic control is difficult in these patients.

\section{Occurrence of raised blood pressure in renal diabetic disease}

INSULIN DEPENDENT DIABETES MELLITUS

The prevalence of hypertension in patients with insulin dependent diabetes defined according to the World Health Organisation's classification, and including patients receiving treatment, is similar in patients with normoalbuminuria and the general population..$^{13}$ The prevalence of hypertension increases sharply in patients with microalbuminuria, and most patients with overt proteinuria have classic hypertension. Soon after the occurrence of microalbuminuria, blood pressure may increase by about $4 \mathrm{~mm} \mathrm{Hg}$ per year. ${ }^{6}$ Therefore the main group of patients with insulin dependent diabetes that are given antihypertensive treatment are those with microalbuminuria or overt renal disease. On the other hand, some patients with insulin dependent diabetes may have raised blood pressure before microalbuminuria-that is, coincidental essential hypertension. ${ }^{13}$ Also, it is important to note that some patients with normoalbuminuria will develop microalbuminuria. This is part of the natural course of the disease because during the first few years of diabetes most patients after metabolic stabilisation will have normoalbuminuria. Renal damage clearly increases the longer the duration of diabetes.

Table 1 Stages of renal disease ${ }^{\star}$ in patients with insulin dependent diabetes

\begin{tabular}{|c|c|c|c|c|c|c|c|}
\hline Stage & Designation & Main characteristics & $\begin{array}{l}\text { Main structural } \\
\text { changes }\end{array}$ & $\begin{array}{l}\text { Glomerular } \\
\text { filtration rate } \\
(\mathrm{ml} / \mathrm{min})\end{array}$ & $\begin{array}{l}\text { Urinary albumin } \\
\text { excretion }\end{array}$ & Blood pressure & Comments \\
\hline $\begin{array}{l}\text { I (at diag- } \\
\text { nosis) }\end{array}$ & $\begin{array}{r}\text { Hyperfunction/ } \\
\text { hypertrophyt }\end{array}$ & $\begin{array}{l}\text { Glomerular } \\
\text { hyperfiltration }\end{array}$ & $\begin{array}{l}\text { Glomerular } \\
\text { hypertrophy }\end{array}$ & $\approx 150$ & May be increased & Normal & $\begin{array}{l}\text { Glomerular } \\
\text { volume/pressure } \\
\text { increase (reversible) }\end{array}$ \\
\hline II & Normoalbuminuria & $\begin{array}{l}\text { Normal urinary } \\
\text { albumin excretion }\end{array}$ & $\begin{array}{l}\text { Increasing basal } \\
\text { membrane } \\
\text { thickness }\end{array}$ & Hyperfiltration $\ddagger$ & $\begin{array}{l}\text { Normal (high } \\
\text { during stress) }\end{array}$ & Normal & $\begin{array}{l}\text { Changes as indicated } \\
\text { above but quite } \\
\text { variable }\end{array}$ \\
\hline $\begin{array}{l}\text { Transition } \\
\text { from } \\
\text { II } \rightarrow \text { III }\end{array}$ & Transition phase & $\begin{array}{l}\text { High normal urinary } \\
\text { albumin excretion }\end{array}$ & Not known & Hyperfiltration & Increasing & Increasing & $\begin{array}{l}\text { Somewhat poor } \\
\text { metabolic control }\end{array}$ \\
\hline III & $\begin{array}{l}\text { Incipient diabetic } \\
\text { nephropathy, } \\
\text { microalbuminuria }\end{array}$ & $\begin{array}{l}\text { Raised urinary } \\
\text { albumin excretion }\end{array}$ & $\begin{array}{l}\text { Urinary albumin } \\
\text { excretion correlated } \\
\text { to structural } \\
\text { damage }\end{array}$ & Still high & $20 \rightarrow 200 \mu \mathrm{g} / \mathrm{min}$ & $\begin{array}{l}\text { Raised compared } \\
\text { with stage II }\end{array}$ & $\begin{array}{l}\text { Advancing glomerular } \\
\text { lesions; } \\
\text { permeability defect } \\
\text { not located }\end{array}$ \\
\hline IV & $\begin{array}{l}\text { Overt diabetic } \\
\text { nephropathy }\end{array}$ & $\begin{array}{l}\text { Clinical proteinuria } \\
\text { or urinary albumin } \\
\text { excretion }>200 \\
\mu \mathrm{g} / \mathrm{min}\end{array}$ & $\begin{array}{l}\text { Advanced structural } \\
\text { damage }\end{array}$ & $\begin{array}{l}\text { "Normal" to } \\
\text { advanced } \\
\text { reduction }\end{array}$ & $>\underset{\mu \mathrm{g} / \mathrm{min})}{200 \underset{10}{\rightarrow} \approx 10000}$ & $\begin{array}{l}\text { Often frank } \\
\text { hypertension } \\
\text { increase by } \\
\approx 5 \% \text { yearly }\end{array}$ & $\begin{array}{l}\text { High rate of } \\
\text { glomerular closure; } \\
\text { severe mesangial } \\
\text { expansion }\end{array}$ \\
\hline $\mathrm{V}$ & $\begin{array}{l}\text { End stage renal } \\
\text { disease }\end{array}$ & Uraemia & $\begin{array}{l}\text { General glomerular } \\
\text { closure }\end{array}$ & Very low & $\begin{array}{l}\text { Decreasing } \\
\text { albuminuria }\end{array}$ & $\begin{array}{l}\text { Often high, } \\
\text { related to } \\
\text { volume } \\
\text { expansion }\end{array}$ & $\begin{array}{l}\text { Death/uraemia } \\
\text { (postponed by ACE } \\
\text { inhibition) }\end{array}$ \\
\hline
\end{tabular}


NON-INSULIN DEPENDENT DIABETES MELLITUS The situation in patients with typical noninsulin dependent (type 2) diabetes is somewhat different. ${ }^{14}$ Many of these patients have hypertension when diabetes is diagnosed, and they may have renal complications when they are first seen. According to a recent survey in general practice in Denmark, more than 30\% of patients with newly diagnosed diabetes had microalbuminuria and about $6 \%$ clinical proteinuria, with a male preponderance. ${ }^{14}$ There is a weak correlation between the degree of albuminuria and blood pressure. Also, many patients are already receiving antihypertensive treatment. Albuminuria also correlated with degree of glycaemia and with triglyceride concentrations. With more advanced renal disease blood pressure tended to increase further, and an even larger proportion of patients require antihypertensive treatment when overt renal disease is present. ${ }^{15}$

\section{Transition from normoalbuminuria to microalbuminuria}

INSULIN DEPENDENT DIABETES MELLITUS New studies measuring ambulatory blood pressure have clearly indicated that transition from normoalbuminuria to microalbuminuria is associated with a concomitant increase in ambulatory blood pressure over 24 hours. The onset of microalbuminuria is always associated with a rise in blood pressure, but the converse is not necessarily true. ${ }^{6}$ In patients developing microalbuminuria the increase in blood pressure was fourfold compared with that in those patients who did not do as well as healthy controls. Therefore, early in the course of renal complications, raised blood pressure is important, although it is difficult to outline clearly the prime abnormality as patients developing microalbuminuria already have albumin excretion rates in the upper part of the normal range, around $10 \mu \mathrm{g} / \mathrm{min}$. These observations suggest a radical new preventive approach. Maybe patients with normoalbuminuria at risk of renal progression should in the future be treated with antihypertensive agents even if they do not have high blood pressure. An important recent prospective study also shows that transition from normo-
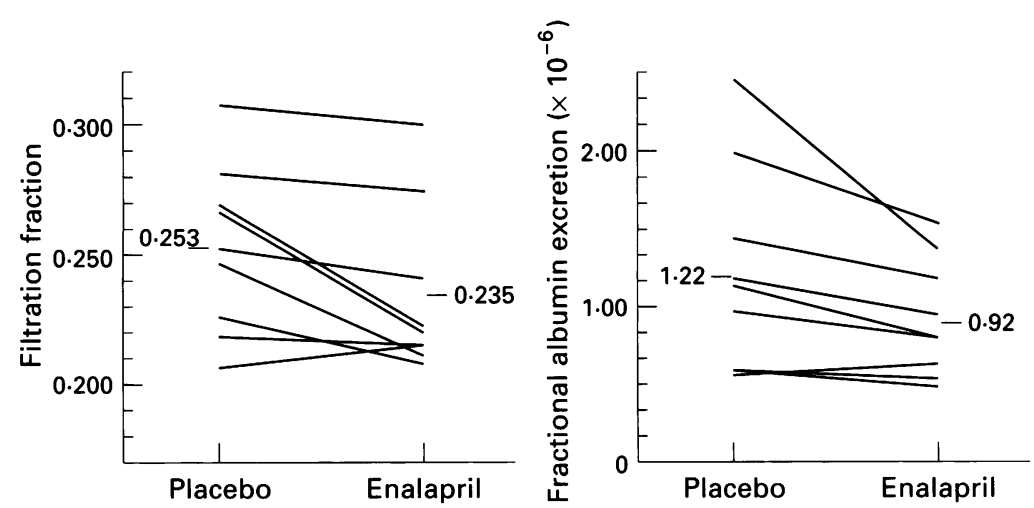

Figure 1 Filtration fraction and fractional albumin clearance after three months of placebo or enalapril $30 \mathrm{mg}$ per day in nine patients with insulin dependent diabetes and normoalbuminuria. ${ }^{18}$ albuminuria (defined as $<30 \mu \mathrm{g} / \mathrm{min}$ : a rather high value) to microalbuminuria $(\geq 30$ $\mu \mathrm{g} / \mathrm{min})$ is associated with higher initial albumin excretion as well as some hypertension. ${ }^{12}$ In patients with microalbuminuria even slight increase in blood pressure promotes progression. ${ }^{3}$

NON-INSULIN DEPENDENT DIABETES MELLITUS Usually there is a gradual increase in albuminuria with time in patients with noninsulin dependent diabetes. In the normoalbuminuric stage, however, many patients remain stable despite a long duration of diabetes. ${ }^{16}$ Albuminuria increases by about $20 \%$ per year, and this is related to the attained blood pressure (A Schmitz, personal communication). This again suggests the deleterious effect of even a slight increase in blood pressure in type 2 diabetes. Glycaemic control is also likely to be affected, but so far there are no published long term studies on optimised diabetes control in patients with type 2 diabetes, although important work is in progress. ${ }^{17}$ Many patients with type 2 diabetes are elderly and have confounding risk factors, so it is hazardous to extrapolate the encouraging data on glycaemic control in patients with type 1 diabetes to this population. ${ }^{11}$

\section{Clinical trials in patients with normoalbuminuria}

INSULIN DEPENDENT DIABETES MELLITUS ACE inhibition in patients with albuminuria is associated with a significant reduction in filtration fraction and fractional albumin clearance (fig 1)..$^{18}$ Importantly, in this study there was no significant change in clinic based blood pressure, although ambulatory blood pressure over 24 hours was not measured. The reduction in filtration fraction could, in theory, be associated with a decrease in hydraulic glomerular pressure, which in turn could explain the reduction in albuminuria. Although it is too early to recommend antihypertensive treatment in such patients, this study underlines interest in clinical trials in this area. Patients at risk of developing microalbuminuria-namely, patients with poor metabolic control (glycated haemoglobin $\left.\left(\mathrm{HbA}_{\mathrm{IC}}\right)>9-10 \%\right)$, some persistent borderline increase in albumin excretion already (> 10-12 $\mu \mathrm{g} / \mathrm{min}$ ), and possibly severe hyperfiltration (glomerular filtration rate $>150 \mathrm{ml} /$ min) - should be enrolled in clinical trials to see whether the development of microalbuminuria can be prevented.

NON-INSULIN DEPENDENT DIABETES MELLITUS Recent studies show that ACE inhibitors reduce blood pressure effectively in patients with non-insulin dependent diabetes, but to reduce albuminuria within normal excretion seems to be difficult. No adverse effect on concentrations of glucose, lipids, or uric acid was seen. ${ }^{19} 20$ Interestingly, low dose diuretic treatment is also effective, which may be because these patients usually retain sodium 
Table 2 Trials resulting in slightly reduced blood pressure in young non-hypertensive patients with insulin dependent diabetes and microalbuminuria or early nephropathy

\begin{tabular}{|c|c|c|c|c|c|}
\hline Reference (year) & Nature of trial & Intervention & $\begin{array}{l}\text { No of patients; } \\
\text { duration of } \\
\text { treatment }\end{array}$ & Microalbuminuria & Comments \\
\hline $\begin{array}{l}\text { Christensen and } \\
\text { Mogensen }^{21}(1985)\end{array}$ & Self controlled, open & $\beta_{1}$ blocker + diuretics & $6 ; 5$ years & Reduced & $\begin{array}{l}\text { Gradual reversal of albuminuria by } \\
\text { antihypertensive treatment }\end{array}$ \\
\hline Marre et al ${ }^{22}$ (1988) & $\begin{array}{l}\text { Double blind, randomised } \\
\text { with parallel controls }\end{array}$ & ACE inhibition & $20 ; 1$ year & Reduced by ACE inhibition & $\begin{array}{l}\text { Untreated patients showed rapid } \\
\text { increase in urinary albumin } \\
\text { excretion (also see figure } 2 \text { ) }\end{array}$ \\
\hline Brichard et al ${ }^{23}$ (1989) & Open & ACE inhibition & $7 ; 1$ year & Reduced by ACE inhibition & \\
\hline Rudberg et al ${ }^{24}$ (1990) & Open & ACE inhibition & $12 ; 6$ months & Reduced by ACE inhibition & Young patients \\
\hline Cook et al ${ }^{25}(1990)$ & Cross over, double blind & ACE inhibition & $12 ; 3$ months & Reduced by ACE inhibition & Children \\
\hline $\begin{array}{l}\text { Melbourne Diabetic } \\
\text { Nephropathy Study } \\
\text { Group }^{26}(1991)\end{array}$ & $\begin{array}{l}\text { Open, randomised with } \\
\text { parallel controls }\end{array}$ & $\begin{array}{l}\text { ACE inhibition } v \\
\text { calcium blocker }\end{array}$ & $43 ; 1$ year & $\begin{array}{l}\text { Reduced by ACE inhibition } \\
\text { and by calcium blocker }\end{array}$ & $\begin{array}{l}\text { Effect mostly seen with raised } \\
\text { blood pressure }\end{array}$ \\
\hline Mathiesen et al ${ }^{27}$ (1991) & $\begin{array}{l}\text { Open, randomised with } \\
\text { parallel controls }\end{array}$ & ACE inhibition & $44 ; 4$ years & Reduced by ACE inhibition & $\begin{array}{l}\text { First study to indicate preservation } \\
\text { of glomerular filtration rate; } \\
\text { proteinuria prevented }\end{array}$ \\
\hline Marre et al ${ }^{28}(1991)$ & $\begin{array}{l}\text { Double blind, randomised } \\
\text { with parallel controls }\end{array}$ & ACE inhibition & $16 ; 6$ weeks & Reduced & $\begin{array}{l}\text { Effect surprisingly not dose } \\
\text { dependent }\end{array}$ \\
\hline $\begin{array}{l}\text { Mau Pedersen et al }{ }^{29} \\
\text { (1991) }\end{array}$ & Open, cross over & $\begin{array}{l}\beta_{1} \text { Blocker }+ \text { thiazide }+ \\
\text { ACE inhibition }\end{array}$ & $8 ; 3$ months & Albuminuria reduced & $\begin{array}{l}\text { Triple treatment may be useful } \\
\text { (early nephropathy) }\end{array}$ \\
\hline $\begin{array}{l}\text { Mau Pedersen et al } \\
\text { (1992) }\end{array}$ & Cross over, double blind & $\begin{array}{l}\beta_{1} \text { Blocker }+ \text { thiazide }+ \\
\text { ACE inhibition }\end{array}$ & $10 ; 4$ months & Albuminuria reduced & $\begin{array}{l}\text { Triple treatment may be useful } \\
\text { (early nephropathy) }\end{array}$ \\
\hline Hallab et $a l^{31}$ (1993) & $\begin{array}{l}\text { Randomised with parallel } \\
\text { controls }\end{array}$ & ACE inhibition & $21 ; 1$ year & Reduced by ACE inhibition & $\begin{array}{l}\text { ACE inhibition more efficient than } \\
\text { thiazide }\end{array}$ \\
\hline Viberti et al ${ }^{32}$ (1994) & $\begin{array}{l}\text { Multicentre, double blind, } \\
\text { randomised with parallel } \\
\text { controls }\end{array}$ & ACE inhibition & $92 ; 2$ years & Reduced by ACE inhibition & $\begin{array}{l}\text { First large scale double blind } \\
\text { study; increase in albuminuria } \\
\text { and proteinuria significantly } \\
\text { prevented }\end{array}$ \\
\hline
\end{tabular}

(S Nielsen, personal communication). It is not yet known whether blood pressure reduction in these patients will result in long term preservation of renal function.

\section{Clinical trials in patients with microalbuminuria}

INSULIN DEPENDENT DIABETES MELLITUS

Over the past decade many clinical trials have been conducted in patients with microalbuminuria, especially patients with insulin dependent diabetes. ${ }^{21-32}$ Firstly, a $\beta_{1}$ blocker plus diuretics were tested, but latterly ACE inhibitors have been studied in particular (table 2). Clearly, a reduction in or stabilisation of microalbuminuria is consistently observed, and progression to overt proteinuria is prevented by ACE inhibition in some studies. $^{22} 2732$ This observation is important because in the natural course of diabetes in the

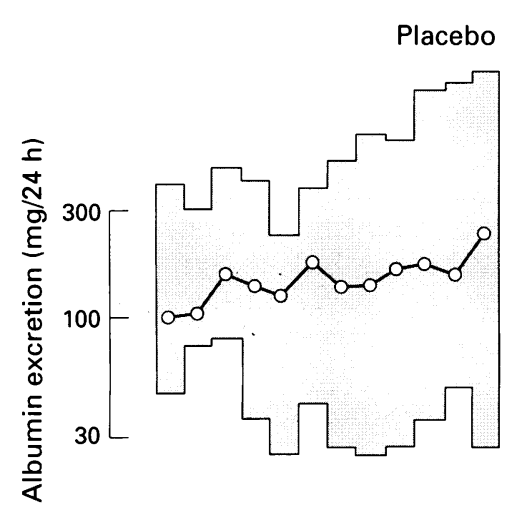

Time effect: $P=0.01$ Linearity: NS
Enalapril

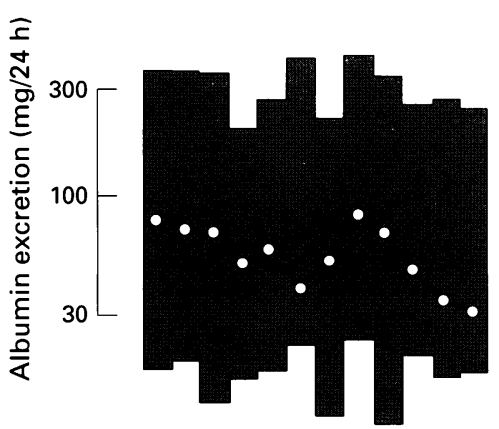

Time effect: $P<0.05$ Linearity: $P=0.01$
Figure 2 Median logarithm of albumin excretion in 10 patients with insulin dependent diabetes treated with placebo and 10 treated with enalapril. Shading shows range of values. Blood pressure decreased significantly with enalapril and increased with placebo. ${ }^{22}$ transition of microalbuminuria to macroalbuminuria there is always a fall in glomerular filtration rate. ${ }^{33}$ On the other hand, patients who remain microalbuminuric usually have well preserved renal function. These observations suggest that antihypertensive intervention, particularly ACE inhibition, should be started early in the phase of microalbuminuria. Blood pressure was not raised according to the WHO criteria, rather it was close to normal mean values. This suggests that intervention should be started irrespective of blood pressure. However, patients with a moderate increase in blood pressure usually show a more rapid progression in albuminuria and a greater risk of progression to overt renal disease. $^{3}$ Therefore some increase in blood pressure strengthens the indication for antihypertensive treatment. In clinics patients should be frequently monitored for microalbuminuria, and in the case of increase over several months or even a year antihypertensive treatment should be started. At the same time metabolic control and general diabetes care should be optimised. One long term study clearly suggests that a drop in glomerular filtration rate is prevented by ACE inhibition combined with diuretics. ${ }^{27}$ This study has now reached eight years with consistent results (E R Mathiesen, personal communication). Only a few side effects were observed in all the trials in table 2. The risk of such intervention is limited and the potential benefit enormous. Recent studies clearly show that from a costbenefit point of view early antihypertensive treatment in the microalbuminuric state is advisable. $^{34}$ It is not yet known if early antihypertensive treatment will ameliorate the course of the other complications seen at a much higher prevalence in patients with microalbuminuria, especially heart disease (left ventricular hypertrophy) and advanced diabetic retinopathy. New studies suggest, however, 

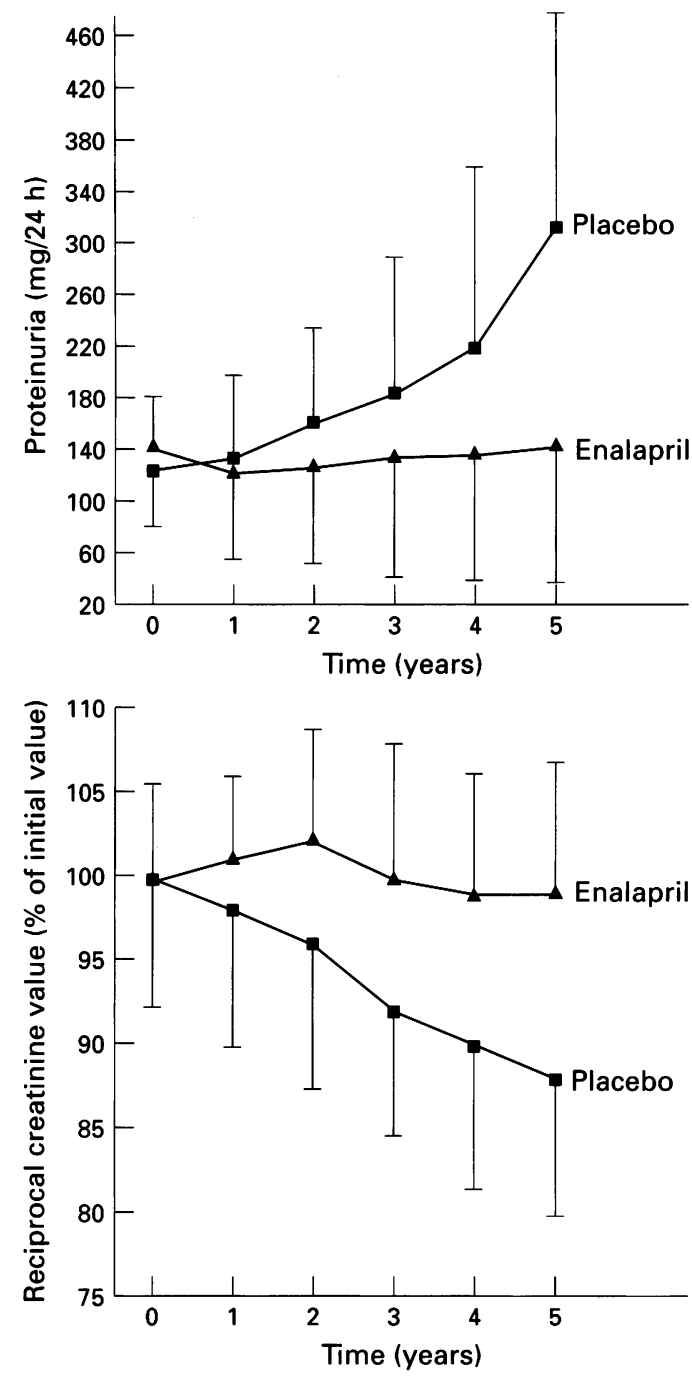

Figure 3 Albuminuria and reciprocal serum creatinine concentrations during five years of follow up of patients with non-insulin dependent diabetes treated with enalapril or placebo. Less proteinuria occurred in the enalapril group compared with placebo group after the second year, and the mean rate of decline in reciprocal creatinine concentration differed between the two groups. ${ }^{36}$

that antihypertensive treatment reduces left ventricular hypertrophy. ${ }^{35}$

Table 3 Observations from clinical trials of $A C E$ inhibition in patients with insulin dependent diabetes

Observation

No trials in patients with newly diagnosed disease

Normoalbuminuria reduced, blood pressure not significantly changed,

Blood pressure reduced (diastolic and systolic), microalbuminuria reduced, fall in glomerular filtration rate prevented ( 8 year follow up)

Blood pressure reduced (diastolic and systolic), proteinuria reduced, rate of fall in glomerular filtration rate reduced

End stage renal disease and death postponed
NON-INSULIN DEPENDENT DIABETES MELLITUS Accumulating evidence suggests that ACE inhibition might be indicated in young patients with type 2 diabetes. Chan et al showed that ACE inhibitors effectively reduced microalbuminuria, an effect which was superior to that of the calcium blocker nifedipine, but this was a fairly short study. ${ }^{20}$ The most impressive study was conducted by Ravid et al, comparing enalapril with conventional antihypertensive treatment, to control for changes in blood pressure (fig 3). ${ }^{36}$ The group given ACE inhibitors showed an initial reduction in albuminuria followed by stabilisation for five years. ${ }^{36}$ A steady increase was observed in the control group. More importantly, an index of glomerular filtration rate-namely, reciprocal serum creatinine concentration-was stabilised by enalapril, whereas in the control group the reciprocal steadily declined. (Eight year follow up provides similar results (M Ravid, personal communication).) The recent study by
Lacourcière et al, shows that microalbuminuria can be reduced by an ACE inhibitor in contrast to conventional treatment, ${ }^{19}$ but they did not find an effect on glomerular filtration rate in the three years of the study. Also, the development of macroalbuminuria was prevented in the patients with consistent microalbuminuria. These three studies point to the importance of early intervention in patients with diabetes and slight albuminuria. Increase in blood pressure further strengthens this indication, as recently shown by Lebovitz et al, who found that a fall in glomerular filtration rate was reduced in microalbuminuric patients by ACE inhibitors. ${ }^{37}$

\section{Overt diabetic renal disease}

INSULIN DEPENDENT DIABETES MELLITUS

Antihypertensive treatment not only reduces albuminuria in patients with overt renal disease but also clearly reduces the rate of decline in glomerular filtration rate. ${ }^{8}$ The initial studies used a combination of $\beta$ blockers and diuretics. Recent studies suggest that ACE inhibitors may have a more pronounced antiproteinuric effect. The most extended study on this subject, by Björck et al, finds that in advanced diabetic nephropathy ACE inhibitors are more efficient, not only in their antiproteinuric effect but also in reducing the rate of decline in glomerular filtration rate (fig 4). ${ }^{38}$ Clearly, much of the effect of antihypertensive agents on the rate of decline in glomerular filtration rate in diabetic patients with nephropathy is related to the effect on blood pressure. ${ }^{3}$ The study by Björck et al suggests that an additional effect is obtained using ACE inhibitors, at least when combined with diuretics. ${ }^{38}$ The superiority of ACE inhibitors was, however, not observed in all studies. ${ }^{39}$

NON-INSULIN DEPENDENT DIABETES MELLITUS Bakris et al studied patients with type 2 diabetes and clinical proteinuria. ${ }^{40}$ Lisinopril and certain calcium blockers not only reduced proteinuria but also reduced the rate of fall in glomerular filtration rate. ${ }^{4041}$ These studies were, however, fairly short term, with a maximal follow up of 1.5 years. ${ }^{41}$ Further studies are needed.

\section{Patients with advanced renal disease}

INSULIN DEPENDENT DIABETES MELLITUS

An interesting end point is the effect on the rate of decline in glomerular filtration rate. In one study captopril delayed the time to doubling of the serum creatinine concentration in patients with overt renal disease and insulin dependent diabetes (fig 5), ${ }^{42}$ reducing mortality and the need for dialysis or renal transplantation. ACE inhibitors were highly effective in reducing the blood pressure in these patients, and this may have accounted for much of the benefit. This is the first controlled study to document a significant effect on critical end points. Table 3 shows that ACE inhibition seems to be effective throughout the course of renal disease in 

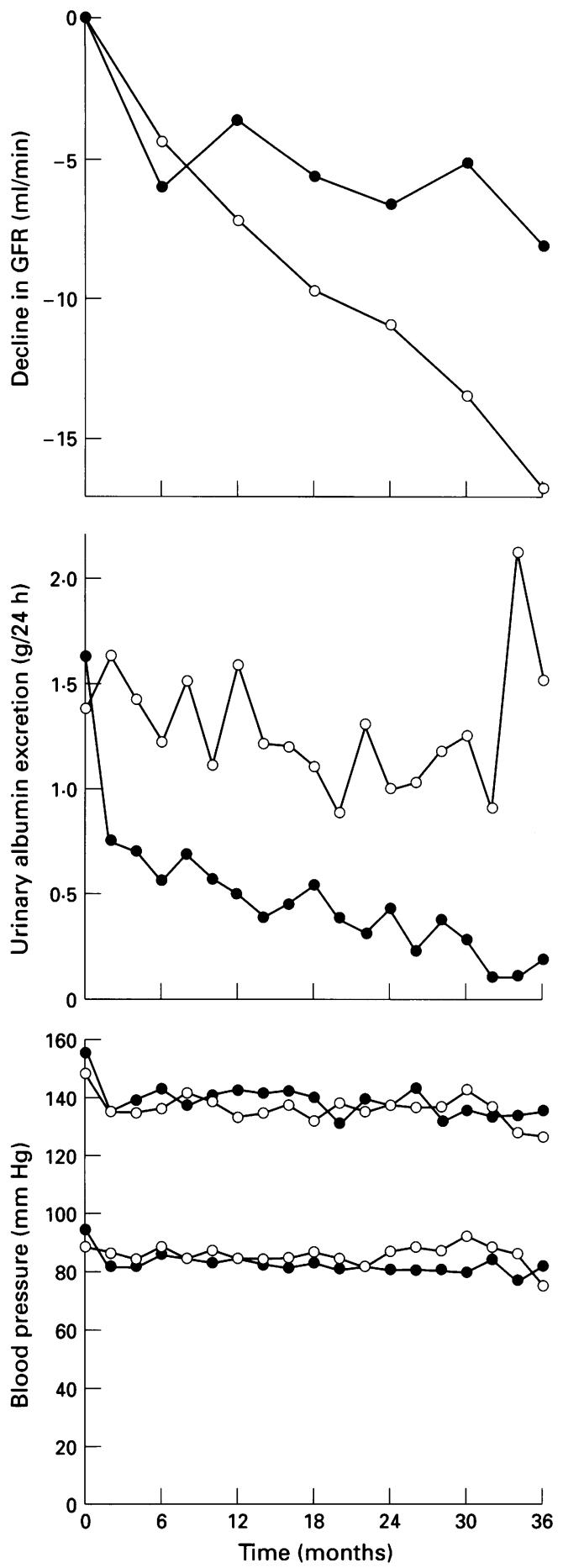

Figure 4 Decline in glomerular filtration rate (GFR), urinary albumin excretion, and blood pressure before and during treatment with enalapril $(\bullet)$ or metoprolol $(0)$ in 40 patients with insulin dependent diabetes and diabetic nephropathy. ${ }^{38}$

insulin dependent diabetes mellitus. The effect is likely to be a class effect, rather than associated with a particular ACE inhibitor.

NON-INSULIN DEPENDENT DIABETES MELLITUS A beneficial effect is also seen in some patients with type 2 diabetes, but the most convincing results are obtained in those with microalbuminuria. With more advanced disease structural vascular damage is probably more advanced, ${ }^{43}$ and the efficacy of antihypertensive treatment may not be so pronounced. This emphasises the need for

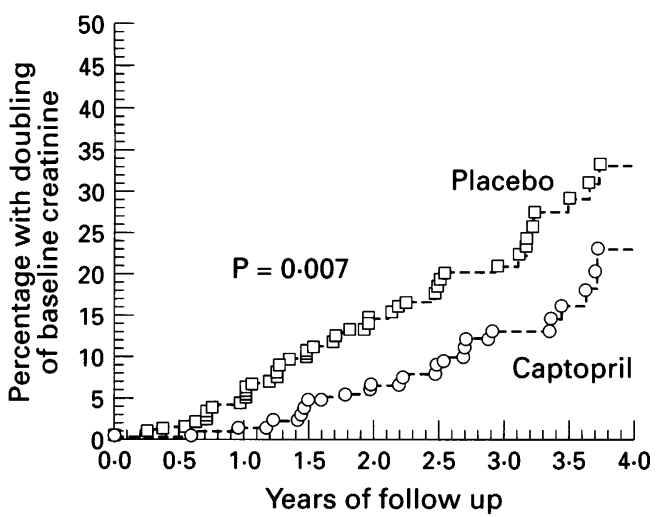

$\begin{array}{llllllllll}\text { Placebo } & 202 & 184 & 173 & 161 & 142 & 99 & 75 & 45 & 22\end{array}$

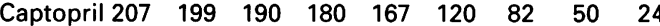

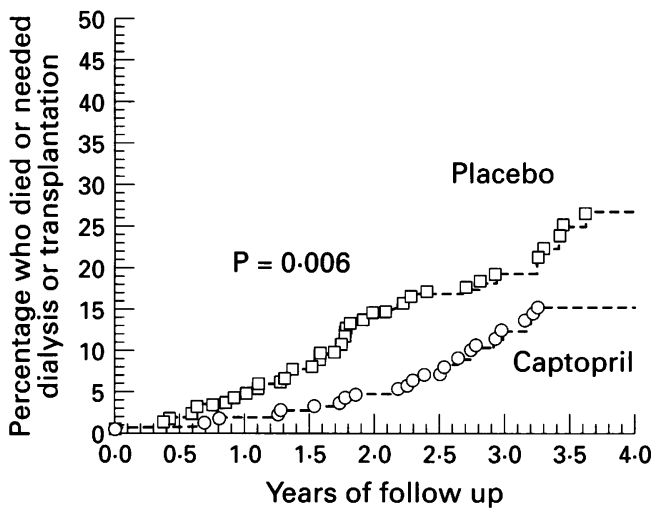

$\begin{array}{llllllllll}\text { Placebo } & 202 & 198 & 192 & 186 & 171 & 121 & 100 & 59 & 26\end{array}$ $\begin{array}{lllllllll}\text { Captopril } 207 & 207 & 204 & 201 & 195 & 140 & 103 & 64 & 37\end{array}$

Figure 5 Cumulative incidence of events in patients with diabetic nephropathy given captopril or placebo. Top: Cumulative percentage of patients with the primary end point: a doubling of the baseline serum creatinine concentration to at least $2.0 \mathrm{mg}$ per $100 \mathrm{ml}$. Bottom: Cumulative percentage of patients who died or required dialysis or renal transplantation. The numbers refer to the numbers of patients in each group at risk for the event at baseline and after each six month period. ${ }^{42}$ Reprinted by permission of the "New England fournal of Medicine" (1993;329:1456-62).

screening patients with type 2 diabetes for microalbuminuria so that treatment is started early.

\section{Possible mechanisms of the} antiproteinuric effect of ACE inhibitors The benefits of ACE inhibition are clear in animal studies, reducing proteinuria and structural glomerular damage in the rat model of diabetes. ${ }^{44}$ The antiproteinuric and renal protective effect of ACE inhibitors probably operate through several mechanisms. A reduction in systemic blood pressure is important, reducing the transmission of the abnormal systemic pressure to the glomerular vessels. This may be especially important in diabetic patients, who may have disturbed autoregulation at the afferent arteriole. ${ }^{45}$ Interestingly, filtration fraction is reduced by ACE inhibition, ${ }^{18}$ which probably reflects efferent arteriolar dilatation associated with a decrease in hydraulic glomerular pressure. Some studies suggest that there may be a direct effect on the permeability of the glomerulus, ${ }^{46}$ but this may also be explained by decreased pressure induced stretch of the 
glomerular vessels. If the hypothesis is correct that proteinuria in itself provokes renal damage by increased mesangial and interstitial flux of protein, a reduction in proteinuria would clearly be beneficial. ${ }^{47}$ Inhibition of growth factors may also be operating. There are many other reports on the effects of ACE inhibitors on renal function and proteinuria, most of which, but not all, have shown benefit and broadly support one or more of the above hypotheses. ${ }^{48-90}$

\section{When to start antihypertensive}

treatment in insulin dependent diabetes

The most recent studies suggest that antihypertensive treatment should be started in the microalbuminuric phase. This treatment should probably be introduced irrespective of blood pressure, but of course with low blood pressure a more conservative attitude should apply. Blood pressure usually increases without treatment during follow up. Some evidence suggests that glomerular filtration rate will remain well preserved if patients remain microalbuminuric or show reduction to normoalbuminuria. ACE inhibitors, often combined with small doses of diuretics, are then particularly useful with limited or no effect on glucose and lipid homoeostasis. Triple treatment with diuretics, ACE inhibitors, and $\beta_{1}$ blockers also seems to be effective. ${ }^{29} 30$

Obviously, careful monitoring for changes in serum potassium concentration as well as glomerular filtration rate (serum creatinine concentration) is warranted, as well as careful control of blood pressure and monitoring of other side effects, especially in more advanced renal disease. Pregnancy or the desire for pregnancy is a clear contraindication for treatment.

The disease process is to some extent similar in the microalbuminuric and macroalbuminuric stages. Since preserving glomerular filtration rate is clearly beneficial in overt renal disease, similar benefits may be assumed among patients with microalbuminuria. This concept is supported by several studies. Importantly, the role of optimising diabetes control has recently been emphasised. ${ }^{11} \mathrm{~A}$ low protein diet may also result in a beneficial effect on renal function. ${ }^{91}$

\section{Brief suggestions for young and middle aged patients with type 2 diabetes}

From a theoretical point of view the same guidelines can be used in patients with noninsulin dependent diabetes as for those with insulin dependent diabetes. Of course, higher blood pressures should be accepted to allow for the age dependent rise in pressure. Patients under 60 years old may be treated similarly to patients with insulin dependent diabetes after the effect of age on blood pressure has been taken into consideration.

So far there are no long term clinical trials in older patients. Experience indicates that ACE inhibition and conventional antihyper- tensive treatment reduce blood pressure effectively in older patients with insulin dependent diabetes. Microalbuminuria may also be reduced, but there are no long term data that glomerular filtration rate is preserved. Generally, the guidelines for younger patients may be acceptable, but a higher blood pressure should be tolerated. If antihypertensive treatment reduces blood pressure and albuminuria with stable glomerular filtration rate, this is probably beneficial. Patients should be carefully monitored for hypotensive and other side effects, which are likely to be more prevalent in older people. insulin-dependent Definition of diabetic renal disease in function tests. In. mellitus. 2nd ed. Dordrecht: Kluwer Academic Publishers, 1994:1-14

2 Rossing P, Hommel E, Smidt UM, Parving H-H. Impact of arterial blood pressure and albuminuria on the progression of diabetic nephropathy in IDDM patients. Diabetes 1993;42:715-9.

3 Mogensen CE, Damsgaard EM, Frøland A, et al. Reduced glomerular filtration rate and cardiovascular damage in diabetes: a key role for abnormal albuminuria. Acta Diabetologica 1992;29:201-13.

4 Mogensen CE. Management of renal disease and hypertension in insulin-dependent diabetes, with an emphasis on early nephropathy. Current Opinion in Nephrology and Hypertension 1992;1:106-15.

5 Mogensen CE. Microalbuminuria, early blood pressure elevation, and diabetic renal disease. Current Opinion in Endocrinology and Diabetes 1994;1:239-47.

6 Poulsen PL, Hansen KW, Mogensen CE. Ambulatory blood pressure in the transition from normo- to microalbuminuria: a longitudinal study in IDDM.
mat a miabetes (in press).

7 Bangstad H-J, Østerby R, Dahl-Jørgensen K, Berg KJ, Hartmann A, Hanssen KF. Improvement of blood glucose control retards the progression of morphological changes in early diabetic nephropathy. Diabetologia 1994;37:483-9.

8 Mogensen CE. Angiotensin converting enzyme inhibitors and diabetic nephropathy: their effects on proteinuria may be independent of their effects on blood pressure. $B M \mathcal{F}$ 1992;304:327-8.

9 Bakris GL. Angiotensin-converting enzyme inhibitors and progression of diabetic nephropathy. Ann Intern Med 1993;118:643-4.

10 Remuzzi G, Ruggenenti P. Slowing the progression of diabetic nephropathy. N Engl F Med 1993:329:1496-7.

11 Diabetes Control and Complications Trial Research Group. The effect of intensive treatment of diabetes on Group. The effect of intensive the development and progression of long-term complications in insulin-depen
Engl f Med 1993;329:977-86.

12 Microalbuminuria Collaborative Study Group, United Kingdom. Risk factors for development of mingdom. Risk factors for development of microalbuminuria in insulin dependent

13 Norgaard K, Feldt-Rasmussen B, Borch-Johnsen K, Sælan $H$, Deckert T. Prevalence of hypertension in type 1 (insulin-dependent) diabetes mellitus. Diabetologia 1990;33:407-10.

14 de $\mathrm{F}$ Olivarius N, Andreasen AH, Keiding N, Mogensen CE. Epidemiology of renal involvement in newlydiagnosed middle-aged and elderly diabetic patients. Cross sectional data from the population-based study "Diabetes Care in General Practice," Denmark. Diabetologia 1993;36:1007-16.

15 Gall M-A, Rossing P, Skøtt P, et al. Prevalence of micro- and macroalbuminuria, arterial hypertension, retinopathy and large vessel disease in European type 2 (non-insulin-dependent) diabetic patients. Diabetologia 1991;34:655-61.

16 Mogensen CE, Schmitz A. Systolic blood pressure relates to the rate of progression of albuminuria in non-insulindependent diabetics [abstract]. Diabetologia (in press).

17 UK Prospective Diabetes Study Group (UKPDS). ViII. Study design, progress and performance. Diabetologia 1991;34:877-90.

18 Mau Pedersen M, Schmitz A, Pedersen EB, Danielsen H, Christiansen JS. Acute and long-term renal effects of angiotensin converting enzyme inhibition in normotensive, normoalbuminuric insulin-
patients. Diabetic Med 1988;5:562-9.

19 Lacourcière Y, Nadeau A, Poirier L, Tancrède G. Captopril or conventional therapy in hypertensive type-II Captopril or conventional therapy in hypertensive type-11
diabetics: 3-year analysis. Hypertension 1993;21:786-94.

20 Chan JCN, Cockram CS, Nicholls MG, Cheung CK, Swaminathan R. Comparison of enalapril and nifedipine in treating non-insulin dependent diabetes associated with hypertension: one year analysis. BMF 1992; 305:981-5. 
21 Christensen CK, Mogensen CE. Effect of antihypertensive treatment on progression of incipient diabetic nephropathy. Hypertension 1985;7(suppl II):II-109-13.

22 Marre M, Chatellier G, Leblanc H, Guyenne T-T, Ménard J, Passa P. Prevention of diabetic nephropathy with enalapril in normotensive diabetics with microalbuminuria. $B M \mathcal{F}$ 1988;297:1092-5.

23 Brichard SM, Santoni JP, Thomas JR, van de Voorde K, Ketelslegers JM, Lambert AE. Long term reduction of microalbuminuria after 1 year of angiotensin converting enzyme inhibition by perindopril in hypertensive insulintreated diabetic patients. Diabetes Metab Rev 1989; 16:30-6.

24 Rudberg S, Aperia A, Freyschuss U, Persson B. Enalapril reduces microalbuminuria in young normotensive type 1 (insulin-dependent) diabetic patients irrespective of its hypotensive effect. Diabetologia 1990;33:470-6.

25 Cook JJ, Daneman D, Spino M, Sochett E, Perlman K, Balfe JW. Angiotensin converting enzyme inhibitor therapy to decrease microalbuminuria in normotensive therapy to decrease microalbuminuria in normotensive
children with insulin-dependent diabetes mellitus. children with insulin-d

26 Melbourne Diabetic Nephropathy Study Group. Comparison between perindopril and nifedipine in hypertensive and normotensive diabetic patients with microalbuminuria. BMf 1991;302:210-6.

27 Mathiesen ER, Hommel E, Giese J, Parving H-H. Efficacy of captopril in postponing nephropathy in normotensive insulin-dependent diabetic patients with microalbuminuria. BMF 1991;303:81-7.

28 Marre M, Hallab M, Billiard A, et al. Small doses of ramipril to reduce microalbuminuria in diabetic patients with incipient nephropathy independently of blood pressure changes. $\mathcal{f}$ Cardiovasc Pharmacol 1991;18(supp 2):S165-8.

29 Mau Pedersen M, Christensen CK, Hansen KW, Christiansen JS, Morgensen CE. ACE-inhibition and renoprotection in early diabetic nephropathy. Response to enalapril acutely and in long-term combination with conventional antihypertensive treatment. Clin Invest Med 1991;14:642-51.

30 Mau Pedersen M, Hansen KW, Schmitz A, Sørensen K, Christensen CK, Mogensen CE. Effect of ACEinhibition supplementary to beta-blockers and diuretics in early diabetic nephropathy. Kidney Int 1992;41: in early

31 Hallab M, Gallois Y, Chatellier G, Rohmer V, Fressinaud $P$, Marre $M$. Comparison of reduction in microalbuminuria by enalapril and hydrochlorothiazide in normotensive patients with insulin dependent diabetes. BMF 1993;306:175-82.

32 Viberti GC, Mogensen CE, Groop L, Pauls JF, for the European Microalbuminuria Captopril Study Group. The effect of captopril on the progression to clinical proteinuria in patients with insulin-dependent diabetes and microalbuminuria. $\mathscr{f} A M A$ 1994;271:275-9.

33 Mogensen CE, Hansen KW, Nielsen S, et al. Monitoring diabetic nephropathy: glomerular filtration rate and abnormal albuminuria in diabetic renal disease. Reproducibility, progression, and efficacy of antihypertensive intervention. Am $\mathcal{F}$ Kidney Dis 1993;22: 174-87.

34 Borch-Johnsen K, Wenzel H, Viberti GC, Mogensen CE. Is screening and intervention for microalbuminuria worthwhile in patients with insulin dependent diabetes? worthwhile in patients
$B M \mathcal{F} 1993 ; 306: 1722-5$.

35 Sampson MJ, Chambers JB, Sprigings DC, Drury PL Regression of left ventricular hypertrophy with 1 year of antihypertensive treatment in type 1 diabetic patien with early nephropathy. Diabetic Med 1991;8:106-10.

36 Ravid M, Savin H, Jutrin I, Bental T, Katz B, Lishner M. Long-term stabilizing effect of angiotensin-converting enzyme inhibition on plasma creatinine and on proteinuria in normotensive type II diabetic patients. Ann Intern Med 1993;118:577-81.

37 Lebovitz HE, Wiegmann TB, Cnaan A, et al. Rena protective effects of enalapril in hypertensive NIDDM: role of baseline albuminuria. Kidney Int 1994;45 S-150-5. 38 Björck $S$, Mulec H, Johnsen SA, Nordén G, Aurell M.
Renal protective effect of enalapril in diabetic nephropathy. BMf 1992;304:339-43.

39 Elving LD, Wetzels JFM, van Lier HJJ, de Nobel E, Berden JHM. Captopril and atenolol are equally effective in retarding progression of diabetic nephropathy. Results of a 2-year prospective, randomized study. Diabetologia 1994;37:604-9.

40 Bakris GL. Hypertension in diabetic patients: an overview of interventional studies to preserve renal function. $\mathrm{Am} \mathscr{f}$ Hypertens 1993;6:140-7S.

41 Slataper R, Vicknair N, Sadler R, Bakris GL. Comparative effects of different antihypertensive treatments on progression of diabetic renal disease. Arch Intern Med 1993;153:973-80.

42 Lewis EJ, Hunsicker LG, Bain RP, Rohde RD, for the Collaborative Study Group. The effect of angiotensinconverting-enzyme inhibition on diabetic nephropathy. $N$ Engl f Med 1993;329:1456-62.

43 Østerby R, Gall M-A, Schmitz A, Nielsen FS, Nyberg G, Parving $\mathrm{H}-\mathrm{H}$. Glomerular structure and function in proteinuric type 2 (non-insulin-depend

44 Vora JP, Anderson S, Brenner BM. Pathogenesis of diabetic glomerulopathy: the role of glomerular hemodynamic factors. In: Mogensen $\mathrm{CE}$, ed. The kidney and hypertension in diabetes mellitus. 2nd ed. Dordrecht: Kluwer Academic Publishers, 1994:223-32.

45 Parving $\mathrm{H}-\mathrm{H}$, et al. Impaired autoregulation of glomerular filtration rate in type 1 (insulin-dependent) diabetic patients with nephropathy. Diabetologia 1984;27: 547-52.

46 Morelli E, Loon N, Meyer T, Peters W, Myers BD. Effects of converting-enzyme inhibition on barrier function in diabetic glomerulopathy. Diabetes 1990;39:76-82.

47 Remuzzi G, Bertani $T$. Is glomerulosclerosis a consequence of altered glomerular permeability to macromolecules? Kidney Int 1990;38:384-94.

48 Taguma Y, Kitamoto Y, Futaki G, et al. Effect of captopril on heavy proteinuria

49 Björck S, Nyberg G, Mulec H, Granerus G, Herlitz H, Aurell M. Beneficial effects of angiotensin converting enzyme inhibition on renal function in patients with diabetic nephropathy. BMF 1986;293:471-4.

50 Hommel E Parving H-H Mathiesen E, Edsberg B, Damkjaer NM, Giese J. Effect of captopril on kidney fumktion in insulin-dependent diabetic patients with nephropathy. BMF 1986;293:479-80.

51 Kelleher CC, Ferriss JB, Cole MM, O'Sullivan DJ Enalapril and microalbuminuria in diabetic and non-diabetic hypertension. $\mathcal{F}$ Hum Hypertens 1987;1: $181-3$.

52 Mimran A, Insua A, Ribstein J, Monnier L, Bringer J, Mirouze J. Contrasting effects of captopril and nifedipine in normotensive patients with incipient diabetic nephropathy. f Hypertens 1988;6:919-23.

53 Parving H-H, Hommel E, Smidt UM. Protection of kidney function and decrease in albuminuria by captopril in
insulin-dependent diabetics with nephropathy. $B M \mathcal{F}$ 1988;297:1086-91.

54 Rett K, Wicklmayr M, Tschollar W, Dietze G, Mehnert H. Role of angiotensin-converting enzyme inhibitors in early antihypertensive treatment in non-insulin dependent antihypertensive treatment in non-insulin depen
diabetes mellitus. Postgrad Med $\mathcal{f}$ 1988;64:69-74.

55 Valvo E, Bedogna V, Casagrande $\mathrm{P}$, et al. Captopril in patients with type II diabetes and renal insufficiency: systemic and renal hemodynamic alterations. $A m \mathcal{F} \mathrm{Med}$ 1988;85:344-8.

56 Abu RS, Nawaz MK, Ali JH, Al SA, Abu JA. Short-term effect of angiotensin-converting enzyme inhibitor enalapril in incipient diabetic nephropathy. Clin Nephrol 1989;31:18-21.

57 Baba T, Murabayashi S, Takebe K. Comparison of the renal effects of angiotensin converting enzyme inhibitor and calcium antagonist in hypertensive type 2 (noninsulin-dependent) diabetic patients with microalbuminuria: a randomised controlled trial. Diabetologia 1989;32:40-4

58 Drummond K, Levy MC, Laborde K, et al. Enalapril does not alter renal function in normotensive, normoalbuminuric, hyperfiltering type 1 (insulin-dependent) diabetic children. Diabetologia 1989;32:255-60.

59 Parving H-H, Hommel E, Damkjaer NM, Giese J. Effect of captopril on blood pressure and kidney function in normotensive insulin dependent diabetics with nephropathy. BMF 1989;299:533-6.

60 Romanelli G, Giustina A, Cimino A, et al. Short term effect of captopril on microalbuminuria induced by exercise in normotensive diabetics. BMF 1989;298:284-8.

61 Stornello M, Valvo EV, Scapellato L. Hemodynamic, renal, and humoral effects of the calcium entry blocker nicardipine and converting enzyme inhibitor captopril in hypertensive type II diabetic patients with nephropathy. hypertensive type II diabetic patients with

62 Stornello M, Valvo EV, Scapellato L. Angiotensin converting enzyme inhibition in normotensive type II diabetics with persistent mild proteinuria. $\mathcal{F}$ Hypertens 1989;suppl 7.

63 Björck S, Mulec H, Johnsen SA, Nyberg G, Aurell M. Contrasting effects of enalapril and metoprolol on proteinuria in diabetic nephropathy. BMF 1990;300: 904-7.

64 Marre M. Microalbuminuria and ACE inhibition in nonhypertensive diabetics. I Diabetes Complications 1990; 4:84-5.

65 Romero R, Salinas I, Teixido J, Lucas A, Felip A, Sanmarti A. Long term follow-up of the effect of captopril on severe proteinuria in hypertensive diabetic patients. $f$ Hum Hypertens 1990;4:671-5.

66 Slomowitz LA, Bergamo R, Grosvenor M, Kopple JD. Enalapril reduces albumin excretion in diabetic patients with low levels of microalbuminuria. $A m f$ Nephrol 1990;10:457-62.

67 Ueda Y, Aoi W, Yamichika S, Shikaya T. Beneficial effects of angiotensin-converting enzyme inhibitor on renal
function and glucose homeostasis in diabetics with hypertension. Nephron 1990;55:85-9.

68 Bursztyn M, Kobrin I, Fidel J, BenIshay D. Improved kidney function with cilazapril in hypertensive type II diabetics with chronic renal failure. $f$ Cardiovasc diabetics with chronic ren

69 Freire MBS, Milagres R, Araujo TMS, et al. Comparative effects of antihypertensive agents upon incipient and effects of antihypertensive agents upon incipient and overt $463-4$.

70 Gonzalez, Sicilia DLL, Garcia AA, et al. Effects of captopril in diabetic nephropathy in hypertensive women. Eur $\mathcal{f}$

71 Haisa S, Norii T, Takatori E, et al. Effects of angiotensin converting enzyme inhibitor (alacepril) and calcium 
antagonist (nicardipine) in hypertensive non-insulindependent diabetic patients with microalbuminuria. $\mathcal{f}$ Diabetes Complications 1991;5:162-4.

72 Holdaas H, Hartmann A, Lien MG, et al. Contrasting effects of lisinopril and nifedipine on albuminuria and tubular transport functions in insulin dependent diabetes. F Intern Med 1991;229:163-70.

73 Romanelli G, Giustina A, Cravarezza P, Caldonazzo A, Agabiti RE, Giustina G. Albuminuria induced by exercise in hypertensive type I and type II diabetic patients: a randomised, double-blind study on the effects of acute administration of captopril and nifedipine. $\mathcal{F}$ Hum Hypertens 1991;5:167-73.

74 Stornello M, Valvo EV, Scapellato L. Comparative effects of enalapril, atenolol and chlorthalidone on blood pressure and kidney function of diabetic patients affected by arterial hypertension and persistent proteinuria. Nephron 1991;58:52-7.

75 Utsunomiya K, Ikeda Y. Beneficial effect of alacepril, a new angiotensin-converting enzyme inhibitor, on albuminuria and glycemic state: an open multicenter trial. Alacepril Study Group. $\mathcal{F}$ Diabetes Complications 1991;5:165-6.

76 Bauer JH, Reams GP, Hewett J, et al. A randomized, doubleblind, placebo-controlled trial to evaluate the effect of enalapril in patients with clinical diabetic nephropathy. Am $₹$ Kidney Dis 1992;20:443-57.

77 Elving LD, Wetzels FJ, de NE, Hoitsma AJ, Berden JH. Captopril acutely lowers albuminuria in normotensive patients with diabetic nephropathy. Am f Kidney Dis 1992;20:559-63.

78 Fioretto P, Frigato F, Riva F, et al. Effects of angiotensin coverting enzyme inhibitors and calcium antagonists on atrial natriuretic peptide release and action and on albumin excretion rate in hypertensive insulindependent diabetic patients. Am $\mathcal{F}$ Hypertens 1992;5: $837-46$.

79 Hermans MP, Brichard SM, Colin I, Borgies P, Ketelslegers J-M, Lambert AE. Long-term reduction of microalbuminuria after 3 years of angiotensin-converting enzyme inhibition by perindopril in hypertensive insulintreated diabetic patients. Am $\mathcal{f}$ Med 1992;92(suppl 4B): 102-7S.

80 Stornello M, Valvo EV, Scapellato L. Persistent albuminuria in normotensive non-insulin-dependent (type II) diabetic patients: comparative effects of
angiotensin-converting enzyme inhibitors and angiotensin-converting enzyme inhibitors

81 Jenkins D, Cowan P, Patrick A, Clarke B. Renal responses to nifedipine and captopril in hypertensive insulindependent diabetic men: a randomized cross-over study. Nephrol Dial Transplant 1993;8:200-5.

82 Nosadini R, Fioretto P, Carraro A, et al. Effects of cliazapril on $\mathrm{Na}$ retention and ANP resistance in IDDM hypertensives. Am f Med 1993;94:66-9S.

83 O'Donnell MJ, Rowe BR, Lawson N, Horton A, Gyde OH, Barnett AH. Placebo-controlled trial of lisinopril in normotensive diabetic patients with incipient nephropathy. F Hum Hypertens 1993;7:327-32.

84 O'Donnell MJ, Rowe BR, Lawson N, Horton A, Gyde OH, Barnett AH. Comparison of the effects of an angiotensin converting enzyme inhibitor and a calcium antagonist in hypertensive, macroproteinuric diabetic patients. 7 Hum Hypertens 1993;7:333-9.

85 Phillips PJ, Phillipou G, Bowen KM, et al. Diabetic microalbuminuria and cilazapril. Am 7 Med 1993. 94:58-60S.

86 Romero R, Salinas I, Lucas A, et al. Renal function changes in microalbuminuric normotensive type II diabetic patients treated with angiotensin-converting enzyme inhibitors. Diabetes Care 1993;16:597-600.

87 Bakris GL. Blood pressure control and progression of diabetic nephropathy: Are all antihypertensive drugs diabetic nephropathy: Are all antihypertensive drugs
created equal? Kidney: A Current Survey of World created equal? Kidney:

88 Molitch ME. ACE inhibitors and diabetic nephropathy. Diabetes Care 1994;17:756.

89 Mulec H, Johnson SA, Björck S. Long-term enalapril treatment in diabetic nephropathy. Kidney Int 1994; 45:S-141-4.

90 Schernthaner G, Schnack CH, Hopmeier P. Effect of ramipril or atenolol on microalbuminuria and metabolic control parameters in type-2 diabetes mellitus (abstract). Diabetologia 1994;37(suppl 1):A195.

91 Walker JD. Non-glycaemic intervention in diabetic nephropathy: The role of dietary protein intake. In: Mogensen CE, ed. The kidney and hypertension in diabetes mellitus. 2nd ed. Boston: Kluwer Academic Publishers, 1994;369-79. 